\title{
Photoproduction of Hydrogen by Decamethylruthenocene Combined with Electrochemical Recycling
}

\author{
Lucie Rivier, Pekka Peljo, Laurent A. C. Vannay, Grégoire C. Gschwend, Manuel A. Méndez, \\ Clémence Corminboeuf, Micheál D. Scanlon, * and Hubert H. Girault*
}

\begin{abstract}
The photoinduced hydrogen evolution reaction (HER) by decamethylruthenocene, $\mathrm{Cp}_{2}{ }^{*} \mathrm{Ru} \mathrm{u}^{I I}\left(\mathrm{Cp}^{*}=\mathrm{C}_{5} \mathrm{Me}_{5}\right)$, is reported. The use of a metallocene to photoproduce hydrogen is presented as an alternative strategy to reduce protons without involving an additional photosensitizer. The mechanism was investigated by (spectro)electrochemical and spectroscopic (UV/Vis and $\left.{ }^{1} H N M R\right)$ measurements. The photoactivated hydride involved was characterized spectroscopically and the resulting $\left[\mathrm{Cp}_{2} * \mathrm{Ru} u^{I I I}\right]^{+}$species was electrochemically regenerated in situ on a fluorinated tin oxide electrode surface. A promising internal quantum yield of $25 \%$ was obtained. Optimal experimental conditionsespecially the use of weakly coordinating solvent and counterions-are discussed.
\end{abstract}

$T_{\text {he development of simple and efficient methods to produce }}$ molecular hydrogen $\left(\mathrm{H}_{2}\right)$ is the focus of intense research. Various state-of-the-art multicomponent artificial photosystems for $\mathrm{H}_{2}$ generation are currently under heavy scrutiny and generally consist of a highly engineered catalyst, photosensitizer, electron mediator or relay combinations, ${ }^{[1]}$ and are often fueled by sacrificial electron donors (for example, triethylamine, ${ }^{[2]}$ triethanolamine, ${ }^{[2 b]}$ benzyl-dihydronicotinamide, ${ }^{[3]}$ and so forth). The latter irreversibly oxidizes upon charge transfer and provides protons and electrons to the catalyst. Consequently, sacrificial systems consume a fuel to produce $\mathrm{H}_{2}$ while electrochemical systems only consume electricity (that is now being increasingly produced in a sustainable manner). Indeed, the electrode can both

[*] L. Rivier, Dr. P. Peljo, G. C. Gschwend, Dr. M. A. Méndez, Prof. H. H. Girault

Laboratoire d'Electrochimie Physique et Analytique (LEPA)

École Polytechnique Fédérale de Lausanne (EPFL Valais Wallis)

Rue de l'Industrie, 17, 1951 Sion (Switzerland)

E-mail: hubert.girault@epfl.ch

Homepage: http://lepa.epfl.ch

L. A. C. Vannay, Prof. C. Corminboeuf

Laboratory for Computational Molecular Design

École Polytechnique Fédérale de Lausanne (EPFL)

Route Cantonal, 33, 1015 Lausanne (Switzerland)

Dr. M. D. Scanlon

Department of Chemistry, the Tyndall National Institute and the Analytical and Biological Research Facility (ABCRF)

University College Cork

Cork (Ireland)

E-mail: micheal.scanlon@ucc.ie

(iD)

Supporting information and the ORCID identification number(s) for the author(s) of this article can be found under http://dx.doi.org/10. 1002/anie.201610240. accept and donate electrons. No irreversible reactions take place at this step, and the protons are supplied from the solution.

Metallocenes appear as an attractive class of molecules capable of achieving the complex photogeneration of $\mathrm{H}_{2}$ by themselves. Indeed, they are able to both reduce protons and undergo photoactivation. Therefore, these "all-in-one" molecules would offer an interesting alternative to state-ofthe-art multicomponent photosystems as fewer electron transfer steps are involved. Moreover, they are simple, easily synthesized molecules, with ligands and metal centers that may be tuned to obtain certain desired properties, such as tailored solubility, absorbance wavelength, or redox potentials.

Recently, we demonstrated the possibility to produce $\mathrm{H}_{2}$ in the dark using decamethylferrocene $\left(\mathrm{Cp}_{2} * \mathrm{Fe}^{\mathrm{II}} ; \mathrm{Cp}^{*}=\right.$ $\mathrm{C}_{5} \mathrm{Me}_{5}$ ) as an electron donor in a biphasic system. ${ }^{[4]}$ Motivated by these early findings, we set out to explore the reactivity of other metallocenes as suitable electron donors. Interestingly, both osmocene $\left(\mathrm{Cp}_{2} \mathrm{Os}^{\mathrm{II}} ; \mathrm{Cp}=\mathrm{C}_{5} \mathrm{H}_{5}\right)^{[5]}$ and decamethylosmocene $\left(\mathrm{Cp}_{2}{ }^{*} \mathrm{Os}^{\mathrm{II}}\right)^{[6]}$ demonstrated the capability to produce $\mathrm{H}_{2}$ upon light irradiation. Other works have proposed the use of a single molecule to achieve photogeneration of $\mathrm{H}_{2}$. For example, Cole-Hamilton ${ }^{[7]}$ reported a platinum phosphine compound, while both Miller ${ }^{[8]}$ and Gray ${ }^{[9]}$ used iridium chloride complexes.

Herein, we report $\mathrm{Cp}_{2} * \mathrm{Ru}^{\mathrm{II}}$ as the first metallocene capable of performing the photogeneration of $\mathrm{H}_{2}$ by itself with subsequent regeneration of the oxidized decamethylruthenocenium cation $\left(\left[\mathrm{Cp}_{2} * \mathrm{Ru}^{\mathrm{III}}\right]^{+}\right)$at a more positive potential than that of proton reduction. The photoelectrocatalytic activity of $\mathrm{Cp}_{2} * \mathrm{Ru}^{\mathrm{II}}$ towards the hydrogen evolution reaction (HER) was determined by electrochemical studies. The general mechanism leading to $\mathrm{H}_{2}$ evolution was studied using (spectro)electrochemistry and spectroscopy (UV/Vis and ${ }^{1} \mathrm{H}$ NMR). This study represents significant progress in the application of light-driven electrochemically reversible metallocenes as key elements in an attractive, viable, and new artificial photosystem that may be incorporated into watersplitting applications.

Photoelectrocatalytic $\mathrm{H}_{2}$ generation by $\mathrm{Cp}_{2} * \mathrm{Ru}^{\mathrm{II}}$ was achieved directly using tetrakis(pentafluorophenyl)borate diethyletherate acid $\left(\left[\mathrm{H}\left(\mathrm{OEt}_{2}\right)_{2}\right] \mathrm{TB}\right)$ as the source of protons in 1,2-dichloroethane (DCE; preparative procedures described in Section 1 of the Supporting Information). All experiments were performed under inert conditions in a glove box. $\mathrm{Cp}_{2} * \mathrm{Ru}^{\mathrm{II}}$ does not require a reductive activation step to be protonated. Thus, in acidified organic solutions, $\mathrm{Cp}_{2} * \mathrm{Ru}^{\mathrm{II}}$ is 
spontaneously converted to $\left[\mathrm{Cp}_{2} * \mathrm{Ru}^{\mathrm{IV}}(\mathrm{H})\right]^{+}$in the dark, as described by Equation (1):

$\mathrm{Cp}_{2}{ }^{*} \mathrm{Ru}^{\mathrm{II}}+\mathrm{H}^{+} \leftrightarrow\left[\mathrm{Cp}_{2}{ }^{*} \mathrm{Ru}^{\mathrm{IV}}(\mathrm{H})\right]^{+}$

The protonation at the metal, which formed the cationic hydride in the dark, was monitored by ${ }^{1} \mathrm{H}$ NMR and UV/Vis spectroscopies (Supporting Information, Section 2).

Earlier studies provided key clues to predict the behavior of photoactivated $\left[\mathrm{Cp}_{2} * \mathrm{Ru}^{\mathrm{IV}}(\mathrm{H})\right]^{+}$during $\mathrm{H}_{2}$ evolution. ${ }^{[10]}$ In particular, it has been assumed that the cationic $\left[\mathrm{Cp}_{2} * \mathrm{Ru}^{\mathrm{III}}\right]^{+}$ species is generated in situ during irradiation of $\left[\mathrm{Cp}_{2} * \mathrm{Ru}^{\mathrm{IV}}\right.$ $(\mathrm{H})]^{+}$in acidified organic solutions (Figure 1). The identifi-

$$
\begin{aligned}
& \mathrm{Cp}_{2} * \mathrm{Ru}^{\mathrm{II}} \underset{+\mathrm{H}^{+}}{\stackrel{\mathbf{C}}{\leftrightarrows}}\left[\mathrm{Cp}_{2} * \mathrm{Ru}^{\mathrm{IV}}(\mathrm{H})\right]^{+} \underset{-1 / 2 \mathrm{H}_{2}}{\stackrel{\mathbf{C}^{\prime}}{\longrightarrow}}\left[\mathrm{Cp}_{2} * \mathrm{Ru}^{\mathrm{III}}\right]^{+} \\
& \text {hv } \\
& \mathbf{E} \\
& {\left[E_{\left[\mathrm{Cp}_{2}^{*} \mathrm{Ru}^{\mathrm{II}^{\prime}}\right]^{+} / \mathrm{Cp}_{2}^{*} \mathrm{Ru}^{\mathrm{II}}}^{\mathrm{O}^{\mathrm{DCE}}}=0.75\right. \text { vs. SHE }}
\end{aligned}
$$

Figure 1. Electrochemical recycling of $\mathrm{Cp}_{2} * \mathrm{Ru}^{\prime \prime}$ by a catalytic $\mathrm{ECC}$ mechanism incorporating light-activated $\mathrm{H}_{2}$ evolution.

cation and characterization of $\left[\mathrm{Cp}_{2} * \mathrm{Ru}^{\mathrm{III}}\right]^{+}$has been obstructed in previous studies because of its high instability and very short lifetime, and $\left[\mathrm{Cp}_{2} * \mathrm{Ru}^{\mathrm{III}}\right]^{+}$was assumed to convert rapidly to $\left[\mathrm{Cp}^{*} \mathrm{Ru}^{\mathrm{IV}}\left(\mathrm{C}_{5} \mathrm{Me}_{4} \mathrm{CH}_{2}\right)\right]^{+} \cdot{ }^{[10 \mathrm{a}-\mathrm{d}]}$ Therefore, we focused our efforts on optimizing the right conditions to stabilize the transient $\left[\mathrm{Cp}_{2}{ }^{*} \mathrm{Ru}^{\mathrm{III}}\right]^{+}$species long enough to allow its electrochemical regeneration and thus obtain a catalytic generation of $\mathrm{H}_{2}$ by a catalytic ECC' mechanism (Electrochemical, Chemical, Chemical) ${ }^{[11]}$ as described in Figure 1.

The influence of solvents and supporting electrolytes on the electrochemical behavior of $\mathrm{Cp}_{2} * \mathrm{Ru}^{\mathrm{II}}$ is discussed in more detail in Section 3 of the Supporting Information. Several studies reporting the formation of $\left[\mathrm{Cp}_{2} * \mathrm{M}^{\mathrm{III}}\right]^{+}$in the presence of a nucleophilic counteranion highlight the instability of the oxidized metallocenes under these experimental conditions. ${ }^{[10 a, 12]}$ Indeed, poorly stabilized $\left[\mathrm{Cp}_{2} * \mathrm{M}^{\mathrm{III}}\right]^{+}$may oxidize a second time to form breakdown products (Supporting Information, Section 3). Furthermore, breakdown of $\left[\mathrm{Cp}_{2}{ }^{*} \mathrm{M}^{\mathrm{II}}\right]^{+}$is accelerated in the presence of coordinating solvents. ${ }^{[10 b, 13]}$ Herein, we describe successful preparation of reasonably stable $\left[\mathrm{Cp}_{2} * \mathrm{Ru}^{\mathrm{III}}\right]^{+}$species (at least on the timescale of the electrolysis experiments) by utilizing the soft tetrakis(pentafluorophenyl)borate counteranion in DCE, and spectroelectrochemically characterizing the production of the $\left[\mathrm{Cp}_{2} * \mathrm{Ru}^{\mathrm{III}}\right]^{+}$species (Supporting Information, Section 3, Figure S5).

The electrochemical behavior of $\mathrm{Cp}_{2} * \mathrm{Ru}^{\mathrm{II}}$ was further characterized by cyclic voltammetry $(\mathrm{CV})$. $\mathrm{CVs}$ of $\mathrm{Cp}_{2} * \mathrm{Ru}^{\mathrm{II}}$ in the absence of acid clearly show an oxidation and a reduction peak for the $\mathrm{Ru}^{\mathrm{III}} / \mathrm{Ru}^{\mathrm{II}}$ redox process with a formal potential of $0.75 \mathrm{~V}$ versus the aqueous standard hydrogen electrode
(SHE; Supporting Information, Section 4). After the addition of excess acid the voltammogram did not show any electrochemical activity inside the potential window because of the production of the protonated $\mathrm{Cp}_{2} * \mathrm{Ru}^{\mathrm{II}}$ species $\left(\left[\mathrm{Cp}_{2} * \mathrm{Ru}^{\mathrm{IV}}-\right.\right.$ $\left.(\mathrm{H})]^{+}\right)$. Subsequently, upon light illumination through the fluorinated tin oxide (FTO) working electrode using a lightemitting diode (LED) light source at $\lambda=365 \mathrm{~nm}$, a clear catalytic current corresponding to the reduction of the photogenerated $\left[\mathrm{Cp}_{2} * \mathrm{Ru}^{\mathrm{III}}\right]^{+}$to $\mathrm{Cp}_{2} * \mathrm{Ru}^{\mathrm{II}}$ appeared with an onset potential slightly positive of the $\left[\mathrm{Cp}_{2} * \mathrm{Ru}^{\mathrm{III}}\right]^{+} / \mathrm{Cp}_{2} * \mathrm{Ru}^{\mathrm{II}}$ redox transition (Figure 2(A), green solid line). No return peak was observed, suggesting a fast protonation of the $\mathrm{Cp}_{2} * \mathrm{Ru}^{\mathrm{II}}$.
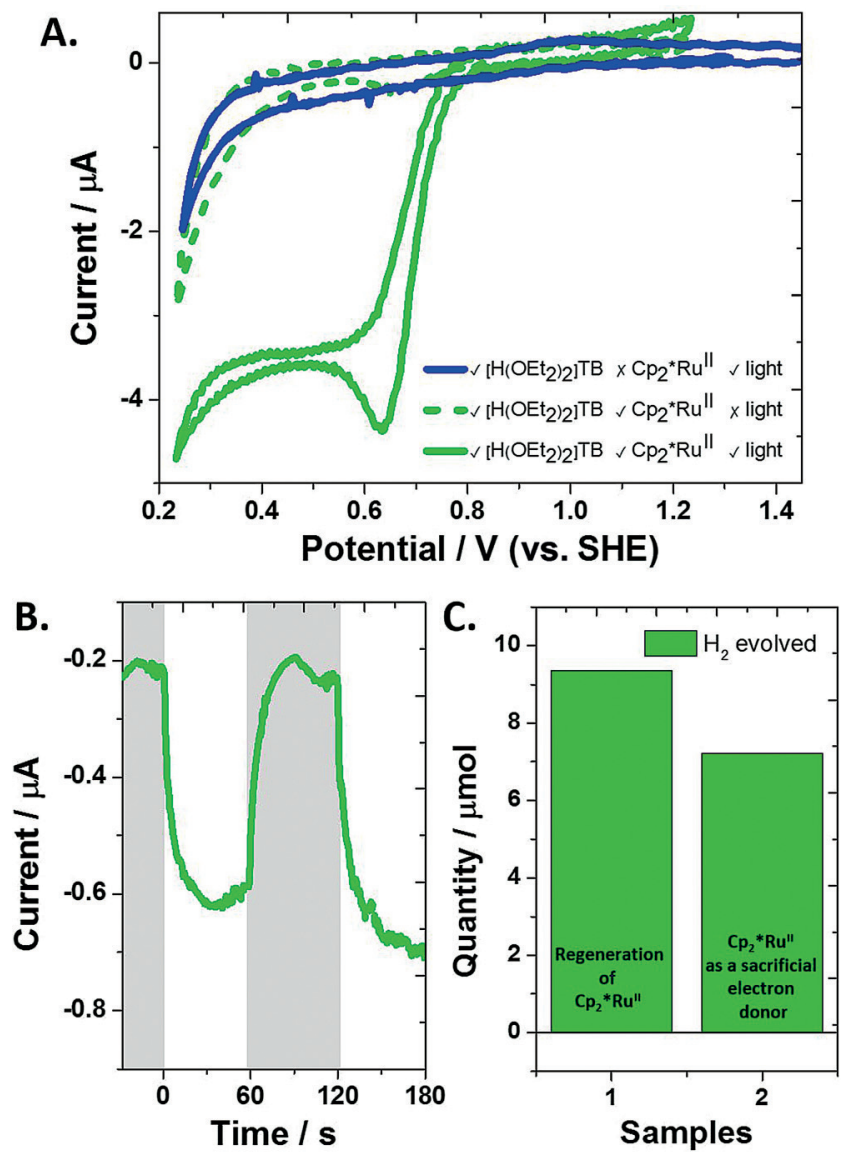

Figure 2. A) $\mathrm{CV}$ of $4 \mathrm{~mm}\left[\mathrm{H}\left(\mathrm{OEt}_{2}\right)_{2}\right] \mathrm{TB}$ in $\mathrm{DCE}$ with $0.1 \mathrm{M} \mathrm{TBAPF}$ supporting electrolyte without (solid blue lines) or with $1 \mathrm{mM} \mathrm{Cp_{2 }} * \mathrm{Ru}^{\prime \prime}$ (green CVs with and without illumination). Scan rate $5 \mathrm{mVs}^{-1}$. B) CPE

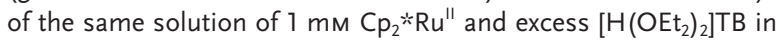
DCE with $0.1 \mathrm{M} \mathrm{TBAPF}_{6}$ as supporting electrolyte on an FTO electrode at $0.50 \mathrm{~V}$ vs. SHE with the LED illumination switched periodically to on (white) and off (gray). The full CPE experimental setup is illustrated in the Supporting Information. C) Identical conditions as (B); the illumination was switched on for $10 \mathrm{~h}$ and $\mathrm{H}_{2}$ production was compared with or without applying a potential to the FTO electrode. The experiment was repeated three times (Supporting Information, Section 5).

The appearance of the reductive catalytic current in the presence of organic protons, $\mathrm{Cp}_{2} * \mathrm{Ru}^{\mathrm{II}}$, and light, was also confirmed by constant potential electrolysis (CPE) per- 
formed at $0.50 \mathrm{~V}$ versus SHE (Figure 2(B); Supporting Information, Section 4). Initially, prior to illumination, almost no current apart from the double-layer charging was observed, in agreement with the CVs generated under these conditions in Figure 2(A). Upon illumination, $\mathrm{Cp}_{2} * \mathrm{Ru}^{\mathrm{II}}$ was immediately oxidized (and $\mathrm{H}_{2}$ evolved, as shown by headspace analysis with gas chromatography; Supporting Information, Section 5) causing the negative current to quickly increase in magnitude because of the regeneration of $\left[\mathrm{Cp}_{2} * \mathrm{Ru}^{\mathrm{III}}\right]^{+}$species at the FTO electrode surface. When the LED was switched off, the current immediately began to drop with the disappearance of the $\left[\mathrm{Cp}_{2} * \mathrm{Ru}^{\mathrm{III}}\right]^{+}$species in the vicinity of the FTO electrode on conversion to $\mathrm{Cp}_{2} * \mathrm{Ru}^{\mathrm{II}}$ and subsequent immediate protonation by $\left[\mathrm{H}\left(\mathrm{OEt}_{2}\right)_{2}\right] \mathrm{TB}$.

The solution turned from colorless to pink after exposure to the LED light. Upon illumination, $\left[\mathrm{Cp}_{2} * \mathrm{Ru}^{\mathrm{III}}\right]^{+}$was also produced in the bulk solution-much too far from the electrode surface to be reduced back to $\mathrm{Cp}_{2}{ }^{*} \mathrm{Ru}^{\mathrm{II}}$ on the timescale of the experiment. Subsequent analysis by UV/Vis spectroscopy revealed a characteristic absorbance band at $500 \mathrm{~nm}$ (Supporting Information, Section 5, Figure S12), identified as the $\left[\mathrm{Cp}_{2} * \mathrm{Ru}^{\mathrm{III}}\right]^{+}$species (Supporting Information, Section 3, Figure S5).

The CPE experiment was repeated overnight 1) without applying a potential and 2) applying a constant potential of $0.50 \mathrm{~V}$ versus SHE (Figure 2(C); Supporting Information, Section 5). More $\mathrm{H}_{2}$ was evolved for the latter confirming the regeneration of the $\left[\mathrm{Cp}_{2} * \mathrm{Ru}^{\mathrm{IV}}(\mathrm{H})\right]^{+}$species and its ability to participate once again in the photodriven HER.

The quantum yield (QY) for the photoelectrocatalytic generation of $\mathrm{H}_{2}$ from an acidified organic solution of $\mathrm{Cp}_{2} * \mathrm{Ru}^{\mathrm{II}}$ is defined as $\mathrm{QY}=2 n_{\mathrm{H}_{2}} / n_{h v}=n\left[\mathrm{Cp}_{2} * \mathrm{Ru}^{\mathrm{III}}\right]^{+} / n_{h v}$. The QY was determined by quantifying the amount of $\left[\mathrm{Cp}_{2} * \mathrm{Ru}^{\mathrm{III}}\right]^{+}$evolved from a $2 \mathrm{~mm} \mathrm{Cp} \mathrm{p}_{2} * \mathrm{Ru}^{\mathrm{II}}$ solution in DCE with excess protons ( $4 \mathrm{~mm}$ ) at a given photon flux by UV/Vis spectroscopy (Supporting Information, Section 6, Figure S13). Details of the calculations are provided in Section 6 of the Supporting Information. An internal QY of $25 \%$ was achieved. Considering the transmittance spectrum of the FTO electrode (Supporting Information, Section 6, Figure S14) the production rate of $\left[\mathrm{Cp}_{2} * \mathrm{Ru}^{\mathrm{III}}\right]^{+}$was recalculated and a theoretical maximum QY of $17 \%$ was determined. Importantly, by following the appearance of $\left[\mathrm{Cp}_{2} * \mathrm{Ru}^{\mathrm{II}}\right]^{+}$spectroscopically to determine the QY, overestimations reached by incorporation of any $\mathrm{H}_{2}$ that may have been produced by degradation of the catalyst were avoided.

The influence of the excitation wavelength was investigated to characterize the transition involved in the photoreaction. Titration by UV/Vis spectroscopy revealed the spectral features of $\left[\mathrm{Cp}_{2} * \mathrm{Ru}^{\mathrm{IV}}(\mathrm{H})\right]^{+}$with a main absorption band at $243 \mathrm{~nm}$ (Supporting Information, Section 2, Figure $\mathrm{S} 3$ ). The maximum production of $\mathrm{H}_{2}$, and $\left[\mathrm{Cp}_{2} * \mathrm{Ru}^{\mathrm{III}}\right]^{+}$ observed at $243 \mathrm{~nm}$ (Supporting Information, Section 7, Figure S15), firmly determined the involvement of electronically excited $\left[\mathrm{Cp}_{2}{ }^{*} \mathrm{Ru}^{\mathrm{IV}}(\mathrm{H})\right]^{+}$in the photoreaction, while also corroborating the photoactivity of $\left[\mathrm{Cp}_{2} * \mathrm{Ru}^{\mathrm{IV}}(\mathrm{H})\right]^{+}$in the near-UV range with a lower but reasonable QY. The absorption spectrum computed at the TD- $\omega$ B97X-D level shows that the main band is dominated by one transition, which induces an electronic enrichment on the hydride position after excitation (Supporting Information, Section 7).

In summary, we have demonstrated the use of a single molecule $\left(\mathrm{Cp}_{2} * \mathrm{Ru}^{\mathrm{II}}\right)$ that is able to photoelectrochemically generate $\mathrm{H}_{2}$ with an internal quantum yield of $25 \% .{ }^{1} \mathrm{H}$ NMR and (spectro)electrochemical studies provided guidelines to understand the mechanism. Looking beyond $\mathrm{Cp}_{2}{ }^{*} \mathrm{Ru}$, we believe that the development of metallocene catalysts for $\mathrm{H}_{2}$ photoproduction could open an interesting new research avenue. Coupled with a light-driven catalyst for water oxidation, such as bismuth vanadate, ${ }^{[14]}$ it has the potential to significantly impact the field of water splitting.

\section{Acknowledgements}

Financial support is acknowledged from the Swiss National Science Foundation, under award numbers 200020_152557 and 20021-156001. This publication has emanated from research by M.D.S. supported in part by a research grant from Science Foundation Ireland (SFI) under Grant Number 13/SIRG/2137. We also acknowledge Dr. Heron Vrubel (LEPA, EPFL) for electrochemical cell manufacturing.

\section{Conflict of interest}

The authors declare no conflict of interest.

Keywords: decamethylruthenocene - electrocatalysis . hydrogen evolution reaction - metallocenes

How to cite: Angew. Chem. Int. Ed. 2017, 56, 2324-2327 Angew. Chem. 2017, 129, 2364-2367

[1] a) A. J. Esswein, D. G. Nocera, Chem. Rev. 2007, 107, 40224047; b) J. L. Dempsey, B. S. Brunschwig, J. R. Winkler, H. B. Gray, Acc. Chem. Res. 2009, 42, 1995-2004.

[2] a) A. Fihri, V. Artero, M. Razavet, C. Baffert, W. Leibl, M. Fontecave, Angew. Chem. Int. Ed. 2008, 47, 564-567; Angew. Chem. 2008, 120, 574-577; b) J. Hawecker, J. M. Lehn, R. Ziessel, Chem. Informationsdienst 1983, 14.

[3] T. Tajima, W. Sakata, T. Wada, A. Tsutsui, S. Nishimoto, M. Miyake, Y. Takaguchi, Adv. Mater. 2011, 23, 5750-5754.

[4] B. Su, I. Hatay, P. Y. Ge, M. Mendez, C. Corminboeuf, Z. Samec, M. Ersoz, H. H. Girault, Chem. Commun. 2010, 46, 2918-2919.

[5] P. Ge, T. K. Todorova, I. H. Patir, A. J. Olaya, H. Vrubel, M. Mendez, X. Hu, C. Corminboeuf, H. H. Girault, Proc. Natl. Acad. Sci. USA 2012, 109, 11558-11563.

[6] P. Ge, A. J. Olaya, M. D. Scanlon, I. Hatay Patir, H. Vrubel, H. H. Girault, ChemPhysChem 2013, 14, 2308-2316.

[7] R. F. Jones, D. J. Cole-Hamilton, J. Chem. Soc. Chem. Commun. 1981, $1245-1246$.

[8] C. L. Pitman, A. J. M. Miller, ACS Catal. 2014, 4, 2727-2733.

[9] H. B. Gray, A. W. Maverick, Science 1981, 214, 1201-1205.

[10] a) A. A. Kamyshova, A. Z. Kreindlin, M. I. Rybinskaya, P. V. Petrovskii, Russ. Chem. Bull. 1999, 48, 581-585; b) M. I. Rybinskaya, A. Z. Kreindlin, R. Hoffmann, R. M. Minyaev, Russ. Chem. Bull. 1994, 43, 1605-1612; c) A. A. Kamyshova, A. Z. Kreindlin, M. I. Rybinskaya, P. V. Petrovskii, Russ. Chem. Bull. 2000, 49, 520-525; d) A. Z. Kreindlin, M. I. Rybinskaya, Russ. Chem. Rev. 2004, 73, 417; e) L. Rivier, T. J. Stockmann, 
M. A. Méndez, M. D. Scanlon, P. Peljo, M. Opallo, H. H. Girault, J. Phys. Chem. C 2015, 119, 25761-25769.

[11] A. J. Bard, L. R. Faulkner, J. Leddy, C. G. Zoski, Electrochemical methods: fundamentals and applications, Vol.2, Wiley, New York, 1980.

[12] a) D. O'Hare, J. C. Green, T. P. Chadwick, J. S. Miller, Organometallics 1988, 7, 1335-1342; b) V. Kölle, J. Grub, J. Organomet. Chem. 1985, 289, 133-139.
[13] A. Z. Kreindlin, P. V. Petrovskii, M. I. Rybinskaya, Russ. Chem. Bull. 1987, 36, 1498-1500.

[14] S. Rastgar, M. Pilarski, G. Wittstock, Chem. Commun. 2016, 52, $11382-11385$.

Manuscript received: October 19, 2016

Revised: November 23, 2016

Final Article published: January 26, 2017 